\title{
小樽市における高齢者の生活環境に関する地理学的研究
}

\section{Geographical Study of Living Environment for the Elderly in Otaru City}

\author{
川村 真也* \\ Shin'ya Kawamura*
}

キーワード：都市施設, 歩行路, GIS, AHP

Key words : urban facilities, sidewalk, GIS, AHP (Analytic Hierarchy Process)

\section{I 、はじめに}

現在，先進諸国における高齢社会の進展に伴 い, 地理学の立場からも様々な視点による研究 が行われている11。特に，高齢社会への転換が 進んだ欧米では，都市に滞留する高齢者の分布 が早くから着目され（Warns,1981；Harper and Laws，1995），都市問題や都市計画と関連づけ た研究が進展している。その中でStutz(1976)や Greenberg (1982) は高齢者の生活環境を都市計画 との関係から論じている。

高齢者の生活行動に関しては，高齢者と非高 齢者の比較や, 加齢による行動空間の縮小等に 関心がよせられ，Corshall(1985)は，高齢層と若 年層の認知距離を比較し, 高齢層の日常生活に おけるモビリティの低下を示唆している。また, Golant (1972), Hanson(1977)は, 高齢者と非高 齢者の外出行動の差が通勤の有無を反映するもの と結論づけている。さらにPeace (1982) は, 高齢 者の様々な属性と生活行動の関連について詳細な 分析をしている。日本にも, そうした高齢者の属 性による外出行動の違いに着目した研究として, 仙田（1993），中鉢（1998）などがある。また, 東京都心部や地方都市の高齢者の行動の比較をし た狩野（1993）, 徳田・前川（1999）や, ニュー タウンを対象とした三谷（1995）らの研究では, 歩行空間に関心が寄せられ，高齢者の歩行特性や 歩行環境の研究がなされている

これまでの研究から, 高齢者にとって居住地付
近における歩行は, 健康状態や社会参加の重要 な指標になることが示唆されており, 歩行しやす い生活環境の確保は地域計画の重要な課題となる と考えられる。とりわけ，北海道のような積雪・ 寒冷地域において, 冬季間は雪と氷で道路が覆わ れ，高齢者にとって歩行は困難となる。実際に寒 冷地の季節差に着目した研究では避難所という観 点から相馬・橋本 (2006) があげられるが, 上述 の歩行や生活環境という視点での研究蓄積は極め て少ない。

そこで本研究では, 積雪寒冷地域における高齢 者の歩行による生活環境を解明することを目的と する。その際，歩行による生活環境下において， 高齢者がどのような都市施設や歩行路を選択・利 用しているのかを把握し, それらの選択・利用し ている環境について, どのような評価をしている のかを解明する。

研究方法は，2 章では小樽市の標高と, 人口 データから高齢者特化指数を算出することで, 小 樽市の高齢者率の高い地区を解明し, 研究対象地 区を設定する。次に，第 3 章では，その地区で実 施した，社会調査の概要を示す。そして当該地域 に扔ける高齢者の歩行による生活環境と, 歩行距 離の比較を行う。最後に第 4 章では, 居住地から 都市施設までの歩行による生活環境の中に存在す る, 医療施設, 商業施設と歩行路の環境に関する 評価をAHPにより解明する。なお, 歩行路に関 しては夏季と冬季で環境状況が異なるために，季

* 北海道大学大学院文学研究科・院生

${ }^{*}$ Graduate Student, Graduate School of Letters, Hokkaido University 
節の違いを考慮に入れ，調査・解析する。

\section{II . 小樽市における高齢者}

本研究の対象地域は小樽市である（図 1 ） ${ }^{3)} 。$ 小樽市における高齢者分布の概要をみるため に，高齢者特化指数を条丁目ごとに算出する（図 2 ），高齢者分布に関する特化指数は以下の式で 表す。

$$
D_{i}=\frac{a_{i} / \sum_{i=1}^{n} a_{i}}{d_{i} / \sum_{i=1}^{n} z_{i}}
$$

ただし $D_{i}$ は小樽市丁目における高齢者の特化指 数, $a_{i}$ は町丁目 ${ }_{i}$ に扔ける高齢者数, $d_{i}$ は町丁目 ${ }_{i}$ に おける人口総数を示している。この式により，小 樽市の町丁目において, 相対的に高齢者人口の卓 越した地域を示すことが可能であり，指数が 1.00 以上であれば，その町丁目の高齢者率は小樽市の 平均值より高いことを示し, 逆に指数が1.00未満 であれば，その町丁目の高需者率は小樽市の平均 值より低いことを示す。図 2 によると，JR南小 樽駅付近等の都心周辺において值が1.00を超えて おり，その地域において人口高齢化の進展が顕著 であることが明らかである。また，郊外において も特化指数の高い地域がみられる。図 2 と図 1 の
小樽市の標高図を重ねあわせてみると，市街地の 急峻な地形に扔いて, 高齢者特化指数の高い地域 が多く，高齢者の生活環境に急峻な坂や階段が 近隣に存在し，歩行による移動が困難な地域であ る。本研究では小樽市の中でも, 上述の急峻な地 形が近隣に存在し，高齢者特化指数の高い花園地 区（都心地区）と奥沢地区（郊外地区）を対象地 域とする。

\section{III. 高齢者の日常生活における歩行空間}

高齢者の生活環境を把握するために，まず，花 園地区，奥沢地区に居住し，主に老人会に所属し ている高齢者（65歳以上）を対象に，2001年10月 から12月にかけて調査票を用いた聞き取り調査を 実施した。

調査票は，ほぼ共通のものを用いたが，調查方 法は花園地区と奥沢地区で異なる。花園地区では 対象者宅を訪問し, 調查の了承を得て, 聞き取り 調查を実施した。奥沢地区では老人会の集会に参 加し，奥沢児童会館にて，対象者に聞き取り調査 を実施した。

花園地区では26名(男10名，女16名)の高齢者に 調査を行い，25人から有効な回答を得た。奥沢地 区では 28 人(男 10 人，女 18 人)の高齢者に調査を行 い，都市施設と歩行ルートの利用に関して，22名

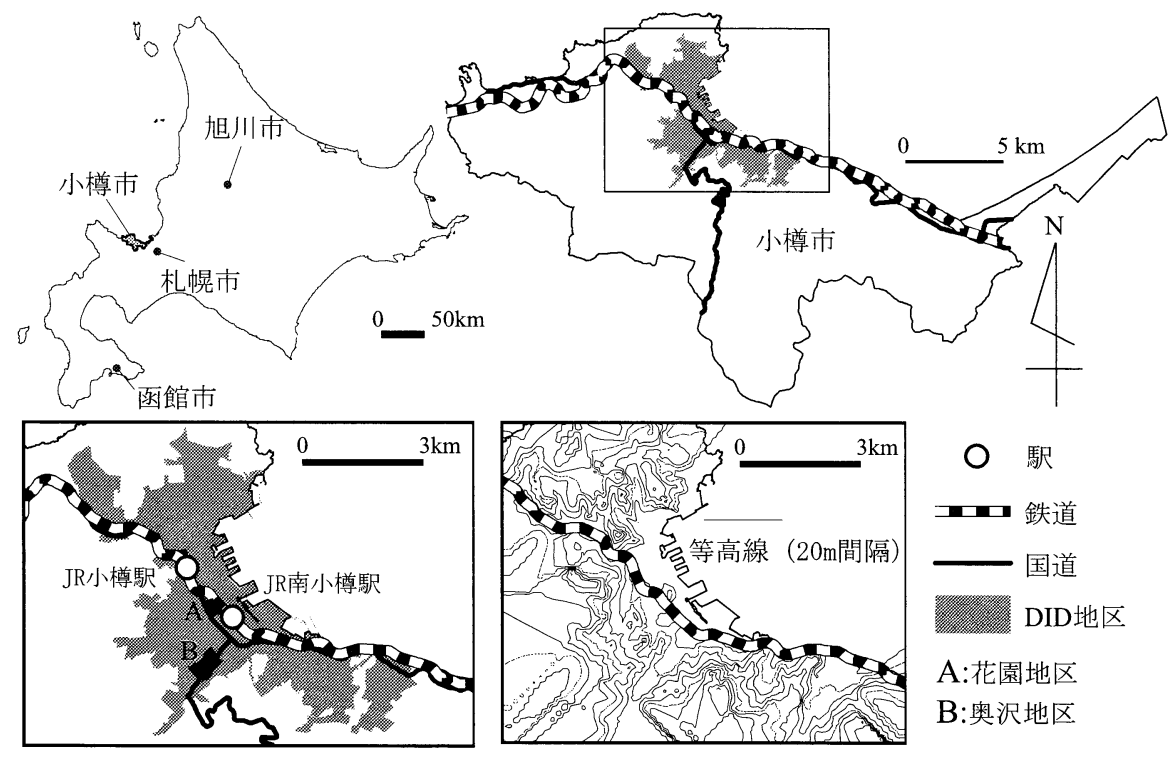

図 1 地域概観図 


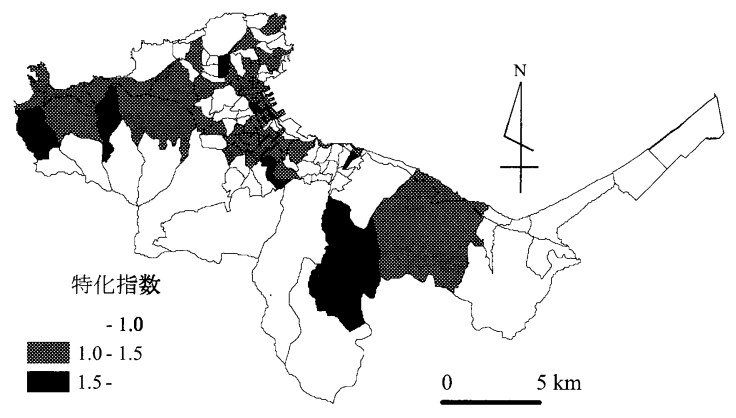

図 2 小樽市における高齢者特化指数

（男性 4 名，女性18名）からそれぞれ有効な回答 を得た。

聞き取りによる調査項目として，まず，日常生 活の中でよく利用する施設を調査した。これは,

1 週間や 1 ケ月間に利用する全ての施設について 調べ，その中でよく利用する医療施設，商業施 設に関して対象を絞り，それら施設に対し，どの くらいの頻度で利用しているのか調査した。さら に，各施設への歩行路については，自宅から都市 施設までの実際に使用している歩行路について調 查をした ${ }^{4)}$ 。歩行路の書き込みは対象者が記入し
たのではなく，対話形式で対象者の行動を調査者 が探りつつ，記入していくやり方を行った。それ らの調査から，様々な歩行パターンを解明する。

まず，花園地区における歩行空間をみる。花 園地区はJR小樽駅とJR南小樽駅のほぼ中間に位 置し, 西方には国道 5 号線があり, 地区の周辺に は百貨店, スーパーなどの小売店, 飲食街, 歓 楽街が隣接して扔り，そうした通りと向かい合う 形で，住宅街が存在している。図 3 ，図 4 による と, 花園地区では施設利用が居住地から徒歩に限 られ, 商業施設への通行量が多く, 生協の利用者 が多い。そして, 後期高齢者を中心に個人病院や 市場の利用も多いことが，この地区の特徴である と考えられる ${ }^{5)}$ 。歩行路に関しては，条件の良い 道への迂回等はみられず，最短のルートを歩行す る傾向がある ${ }^{6)}$ 。

次に，奥沢地区における歩行空間をみる。奥沢 地区は南小樽駅から約 $3 \mathrm{~km}$ の距離に位置し, 勾配 の急な斜面では1960年代から住宅開発が行われ， 勝内川沿いの平坦な地域では，山からの伏流水を 利用した工業地域が存在する。図 5 , 図 6 による と, 奥沢地区では地域内に徒歩で利用できる施設
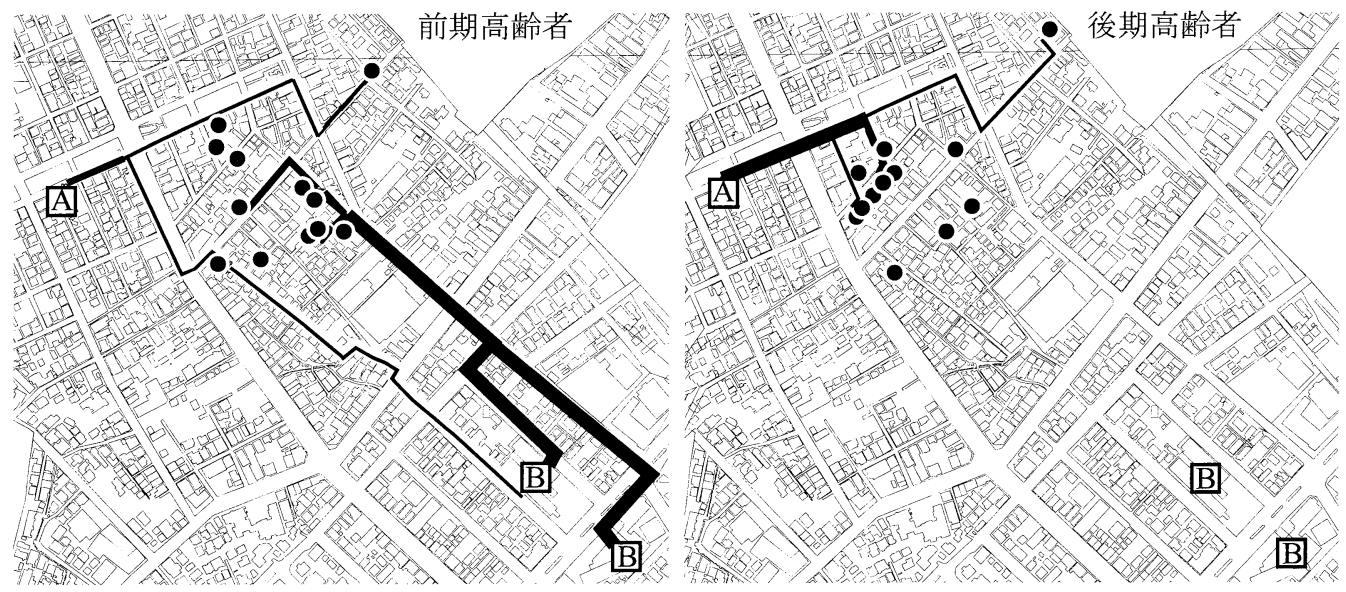

0 $100 \mathrm{~m}$

医療施設

\section{$\mathrm{A}$,個人病院}

$B$,総合病院

- 高齢者世帯
1 ケ月あたりの歩行路通行量

$$
\begin{aligned}
& 50 \text { 回以上 } \\
& 25 \sim 49 \text { 回 } \\
& -15 \sim 24 \text { 回 } \\
& -10 \sim 14 \text { 回 }
\end{aligned}
$$$$
\text { - } 9 \text { 回以下 }
$$

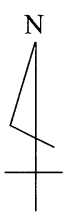

図 3 医療施設への行動パターン（花園地区） 


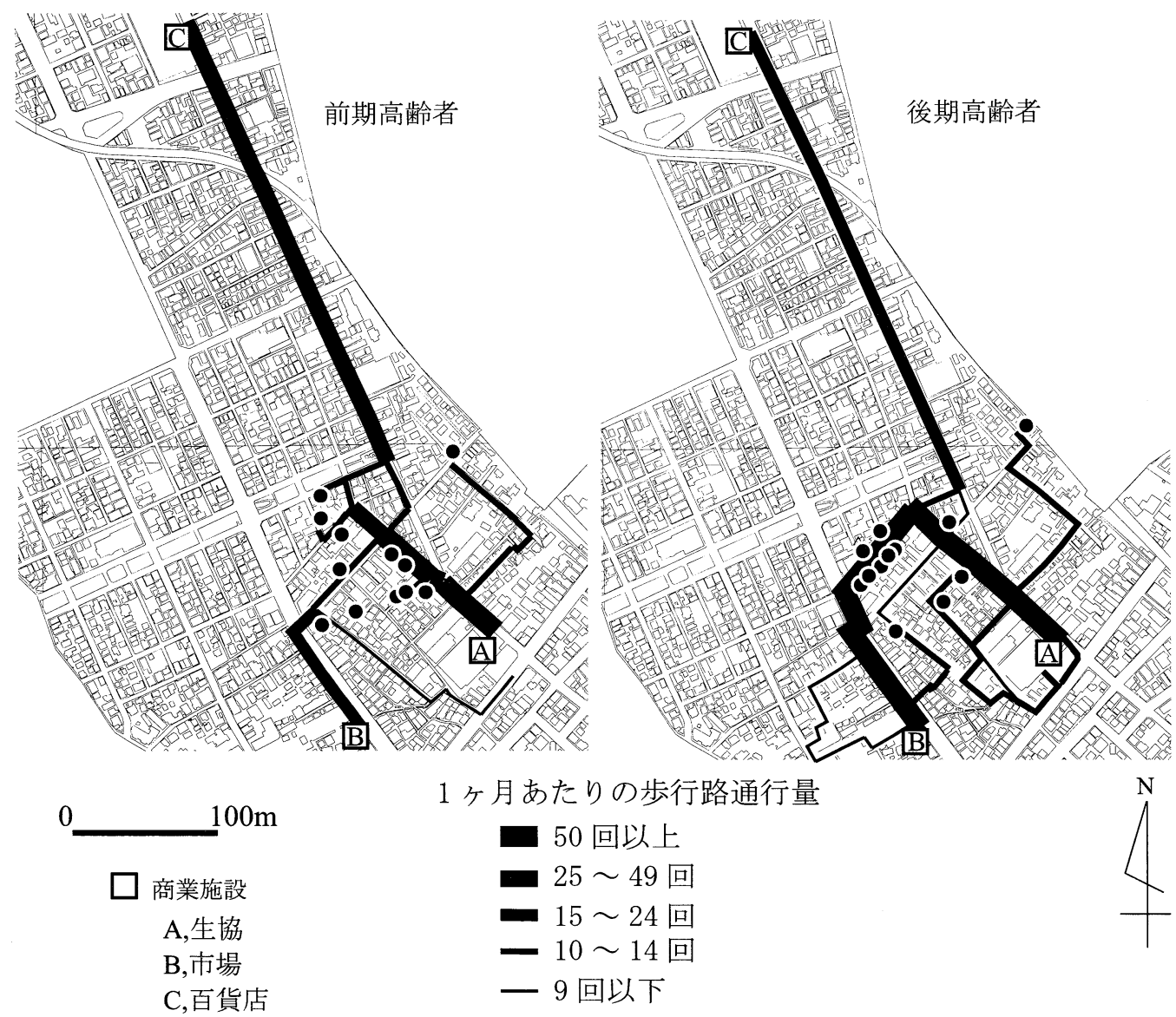

図4 商業施設への行動パターン（花園地区）

が少ないためにバスの利用も多い。特に医療施設 は徒歩で行くことが可能な施設がほとんどなく， 施設利用に関してバスを使用する高齢者が多い ${ }^{7)}$ 。 その点が花園地区との大きな違いである。

奥沢地区では生協が唯一の大型小売店であり, 属性の違いに関わらず利用者が多い。そのため施 設利用について花園地区ほど明確な違いがみられ ない。歩行路は工業地区の広大な敷地が障壁とな り，国道ルートと川沿いルートの間の縦貫的な往 来を妨げていることも影響して, 複数の対象者が 類似した歩行路を利用している。

ここで，花園地区と奥沢地区における歩行路 の長さの差を計測すると（図 7 ）, 花園地区より も奥沢地区の居住者の歩行路が, 約 2 倍の長さと なっていることが明らかになる。各地区における 前期高齢者と後期高齢者の歩行路の長さの差をみ ると, 花園地区ではいずれも $400 \mathrm{~m}$ 前後, 奥沢地
区ではいずれも医療施設では $1,000 \mathrm{~m}$ 前後, 商業 施設では $800 \mathrm{~m}$ 前後となり，年齢層の違いによる 移動距離の差はあまりみられない。

\section{IV．高齢者の生活環境評価}

\section{AHPの概要}

高齢者が生活環境にどのような評価をしている のか解明するために，上述の歩行パターンで示さ れた都市施設と歩行路を生活環境とみなし，それ らに関する評価要因の解析をおこなう。

解析にはAHP（階層分析法）という手法を用 いて評価得点を測定する（図 8） ${ }^{8)}$ 。AHPは主 観的な判断とシステムアプローチを合わせた問題 解決型の意思決定手法の一つであり（刀根・真鍋 編，1990）, 手法としてのAHP最大の利点は, 高齢者の意識を反映した複数の評価項目と都市施 設や歩行路との関係を構造的に把握できるところ 

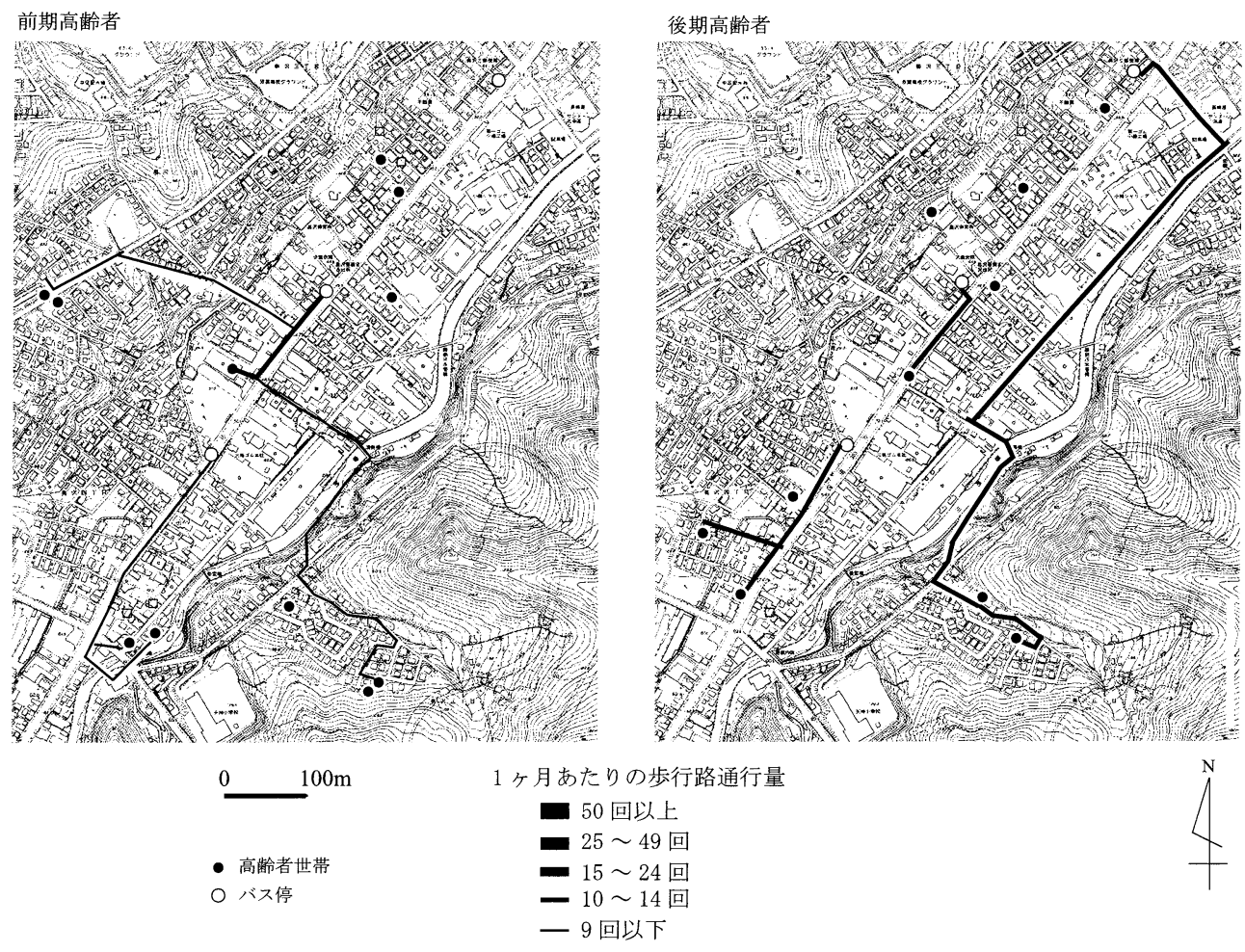

図 5 医療施設への行動パターン（奥沢地区）
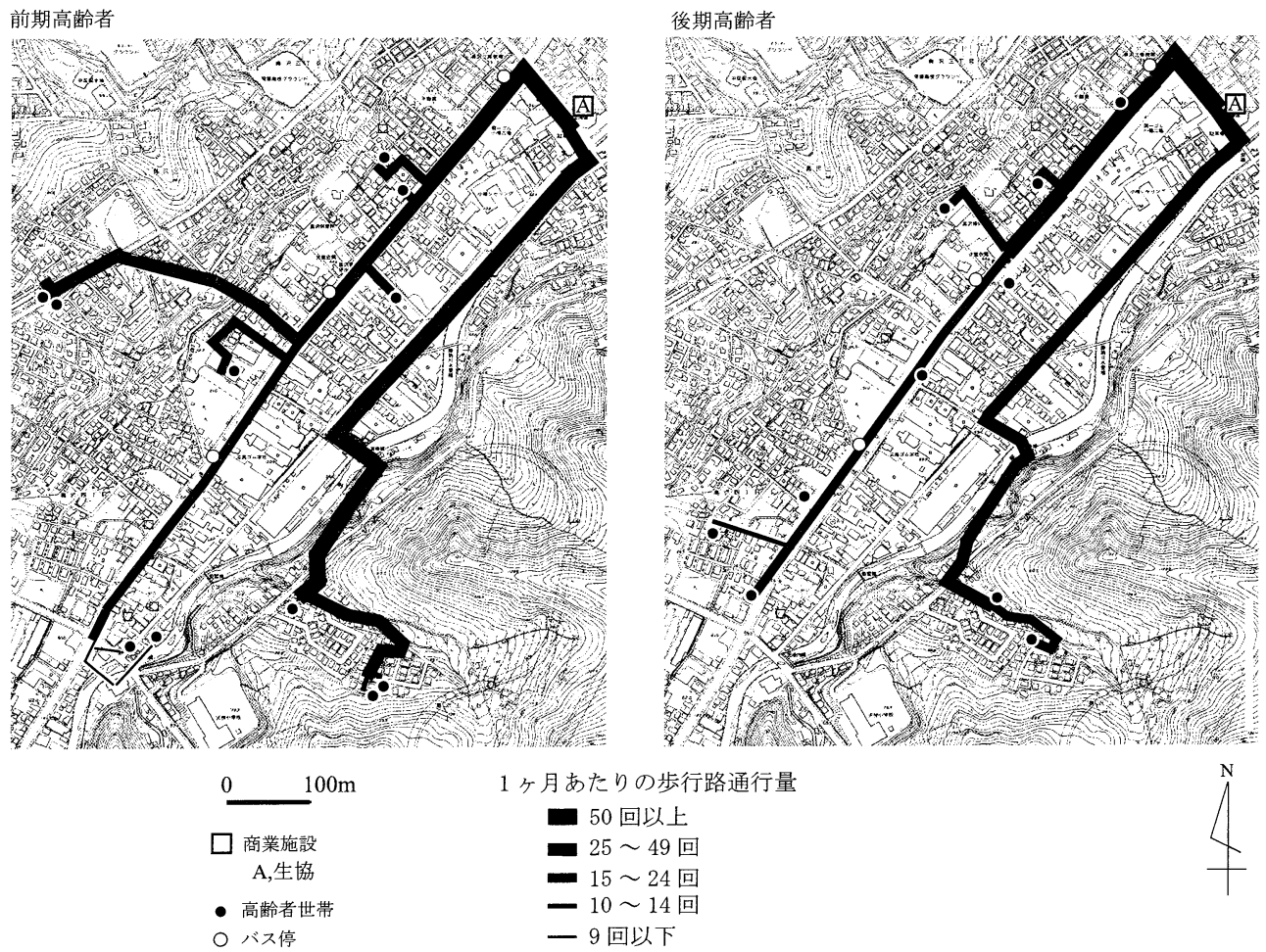

図 6 商業施設への行動パターン（奥沢地区） 
医療施設への平均歩行距離（1度の歩行）

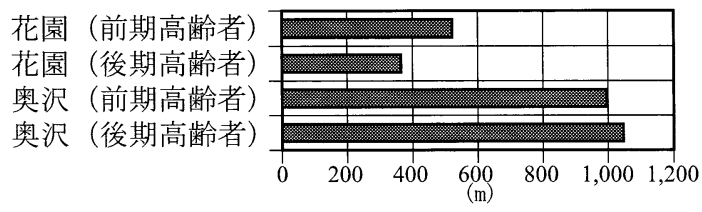

商業施設への平均歩行距離（1度の歩行）

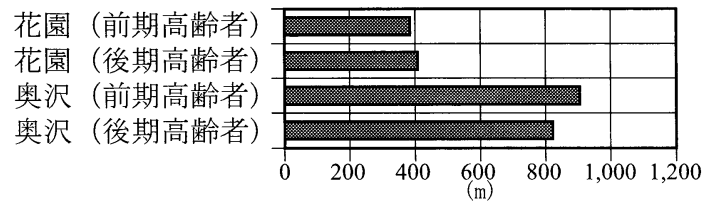

図 7 高齢者の歩行距離

にある。この手法を用いることで単純に都市施設 や歩行路の様々な項目について，「良い」，「悪 い」という意思表示だけでなく，ウェイトによっ て評価の度合いを明らかにすることができる（榊 原・萩原, 2004）。

AHPは一般に合意形成を円滑に行うための 手法として用いられるが, 最近は木下（1990） のように整備する道路の優先順位をつけるため の解析がなされ, 石崎 (1998), Siddiqui et al. （1996），星田（2006）ではGISとAHPの結果を 組み合わせることで, 空間的な環境分析に適応 させており，本研究ではそれらの先行研究を参考 に，高齢者の生活環境に関する主観的な評価につ

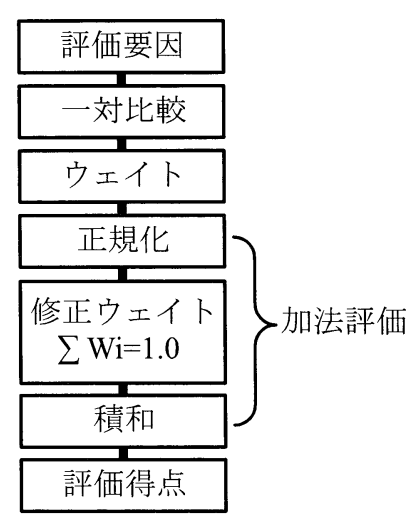

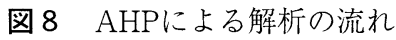

いて解析を行う。さらに, 解析結果を上述の歩行 パターンと関連させてみることで生活環境を空間 的な視点で考察する。

本研究では, 前章で記した歩行パターンの調査 と同時に, 都市施設と歩行路の評価に関する調査 についても同時に行っている。施設や歩行路への 各評価項目について解説する（図 9）。

都市施設（医療施設, 商業施設) は, (1)施設 の魅力要因 ${ }^{9)}$ (2)施設の雲囲気・コミュニティ ${ }^{10)}$

(3)居住地からの利便性の 3 項目を取り上げ, そ れらの評価項目間の得点から，医療施設ではA： 個人医院と B：総合病院間で解析を行う。さらに 商業施設では, 商業形態の異なる $\mathrm{A}$ ：生協（スー
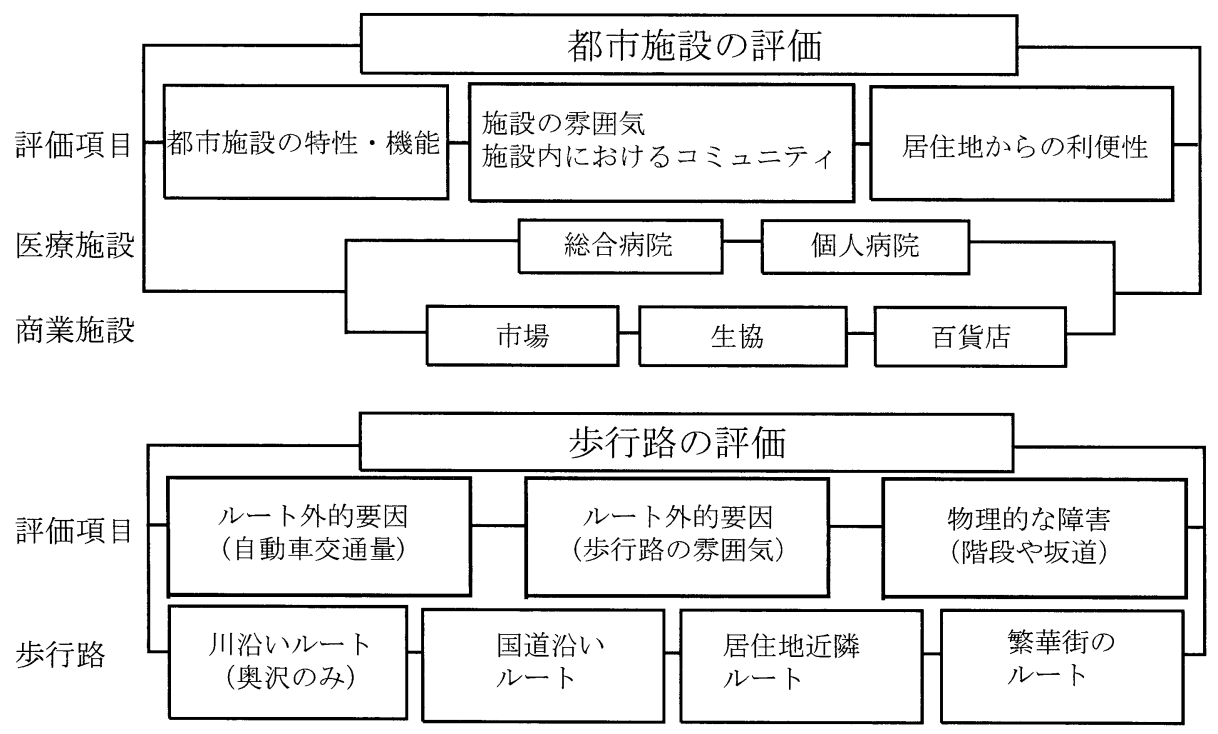

図 9 本研究におけるAHPの階層構造 
パーマーケット)，B：市場，C：百貨店の 3 施 設間で解析を行う。

歩行路は, (1)歩行路の外的要因 $1^{11)}$, (2)歩行 路の外的要因 $2^{12)}$, (3)物理的な障害 ${ }^{13)}$ の 3 項目 を取り上げ，それらの評価項目間の得点から，形 態の異なる $\mathrm{A}$ ：川沿いルート, $\mathrm{B}$ ：国道ルート, $\mathrm{C}$ ：近所ルート, D：繁華街ルートの 4 ルートの 解析をする。

上述の A：川沿いルートは奥沢地区だけ存在す るルートであり, 花園地区では川沿いルートが存 在しないために, 評価得点の算出は行わないこと とする。

\section{2. 都市施設における解析}

都市施設に関する解析結果を図10〜13，表 1 に 示す。花園地区の医療施設評価では, 複数の評価 要因の項目のうち, 「施設の特性」が高く重視さ れ，奥沢地区に比べて「利便性」があまり重視さ れないという特徴がある。これは花園地区が都心 に隣接し，そこに居住する高齢者にとって医療施 設の選択肢が多く存在するため, 特定の医療施設 に依存せずとも「施設の特性」によって，より良 い施設を選択できることが影響していると考えら れる。一方, 奥沢地区では, 評価要因の項目にお いて，前期高齢者では「利便性」が重視され，後 期高齢者では「施設の特性」が高い值を示すが, 前期高齢者と同様に「利便性」の值も高い。医療 施設への歩行パターン（図５）を参照しながら考 慮すると, 奥沢地区には徒歩のみで通院可能な医

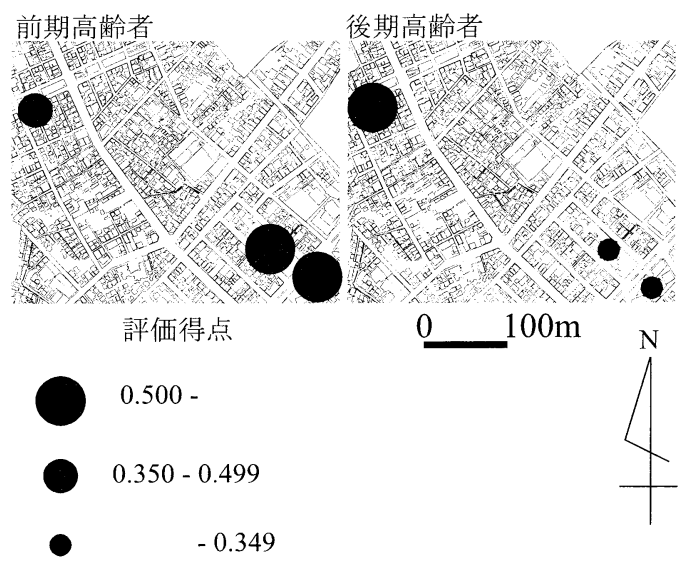

図10 医療施設の評価得点（花園地区）
療施設が地域に存在しないために, 利用する医 療施設の多くが都心に存在する。そのために高齢 者が医療施設への近接性を重視している結果であ ると考えられる。両地区の医療施設への評価得点 をみると，花園地区では前期高齢者で総合病院の 得点が高く, 後期高齢者では個人病院の評価が高 い。どちらも「施設の特性」という項目が重視さ れた結果であるにも関わらず，医療施設の選択が 2 つの属性で全く異なるという, 前期高齢者と後 期高齢者の思考特性の違いが明らかになった。

奥沢地区では, 個人病院と総合病院の得点の差 が極めて少なく（図10, 図11）, 花園地区のよう な評価得点の差がみられない。これは，医療施設 へのバスによる利用が多く, 総合病院のように, バスによる交通アクセスの良い特定施設に大きく 依存する奥沢地区の高齢者の特徵であると考えら れる ${ }^{14)}$ 。

次に, 商業施設をみると, 花園地区の評価要因 では, 前期高齢者と後期高齢者も「利便性」の值 が高く，それに関連して施設では「生協」の評価 得点が高い傾向にある（図12）。歩行パターンと 関連させてみると（図 4)，「生協」は花園地区 のどの高齢者にとっても利用しやすい場所に立地 しているため, 上述の「利便性」が重視された結 果, 「生協」が高い評価得点を得られたと考えら

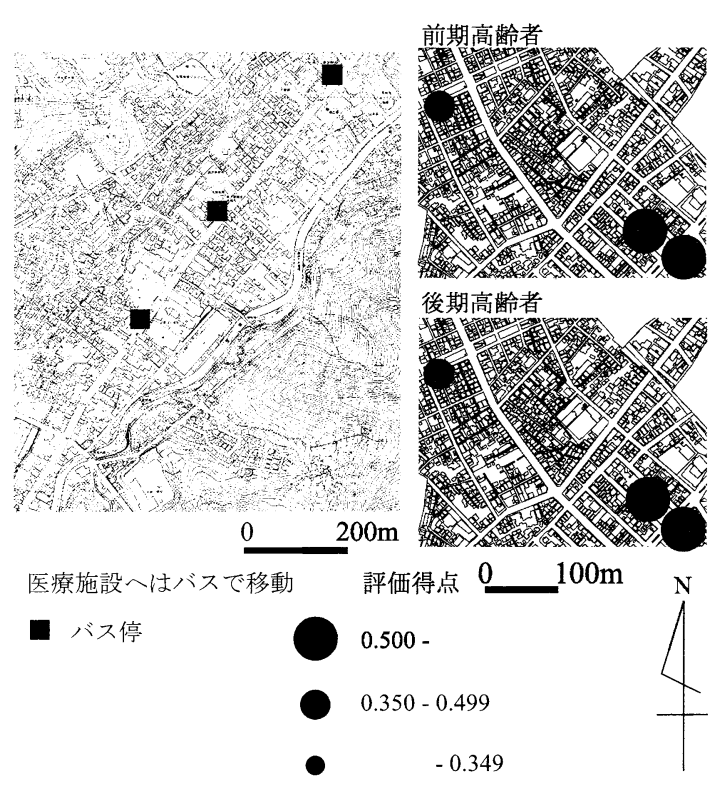

図11 医療施設の評価得点 (奥沢地区) 
表 1 都市施設における評価ウエイトと評価得点 医療施設

\begin{tabular}{l|c|c|c|c}
\hline \multirow{2}{*}{} & \multicolumn{2}{|c|}{ 前期高齢者 } & \multicolumn{2}{c}{ 後期高齢者 } \\
\cline { 2 - 5 } & 花園 & 奥沢 & 花園 & 奥沢 \\
\hline 施設の特性 & 0.483 & 0.204 & 0.458 & 0.429 \\
施設の䨌囲気 & 0.097 & 0.104 & 0.186 & 0.199 \\
居住地からの利便性 & 0.420 & 0.692 & 0.356 & 0.372 \\
\hline 個人病院 & 0.387 & 0.498 & 0.683 & 0.454 \\
総合病院 & 0.613 & 0.502 & 0.317 & 0.546 \\
\hline
\end{tabular}

商業施設

\begin{tabular}{l|c|c|c|c}
\hline \multirow{2}{*}{} & \multicolumn{2}{|c|}{ 前期高齢者 } & \multicolumn{2}{c}{ 後期高齢者 } \\
\cline { 2 - 5 } & 花園 & 奥沢 & 花園 & 奥沢 \\
\hline 施設の特性 & 0.360 & 0.391 & 0.322 & 0.305 \\
施設の需囲気 & 0.122 & 0.132 & 0.271 & 0.207 \\
居住地からの利便性 & 0.518 & 0.477 & 0.407 & 0.488 \\
\hline 市場 & 0.242 & 0.228 & 0.379 & 0.249 \\
生協 & 0.444 & 0.416 & 0.359 & 0.356 \\
百貨店 & 0.314 & 0.356 & 0.262 & 0.395
\end{tabular}

れる。また，後期高齢者は「市場」の評価得点が 一番高いが, その理由として, 後期高齢者にとっ て「市場」との近接性が高いこと, さらに, 前 期高齢者と違い, 「施設の雾囲気」の項目の高さ が評価得点に関連していると考えられる。一方, 奥沢地区でも「利便性」の要因が高い值を示す。 商業施設の評価得点をみると, やはり「生協」の 得点が高い（図13）。奥沢地区では, 物理的に歩 行によって利用できる商業施設が「生協」しかな く, 評価項目を考慮すると, 評価得点の高さは歩
行によって利用できる点が大きいと考えられる。 さらに，花園地区と比べると「市場」の評価得点 が低いことが大きな特徴である。これは地区内 に「市場」が存在せず，「市場」の浸透が薄いこ と, さらに市場よりもバスでの移動が容易な「百 貨店」への依存度が高いことが影響していると考 えられる。

上記の結果をみると, 都心地区は歩行による近 さを意識しているのに対し，郊外地区はバスを伴 う移動が多いので，時間距離による近さを意識し ていることが明らかになった。

\section{3. 歩行路における解析}

歩行路に関する解析結果は図14～図17, 表 2 に 示す。な扮, 歩行路については冬季と夏季を想定 して調査をした ${ }^{15)}$ 。両地区の夏季の歩行路の解 析結果から共通の特徴として, 坂道, 階段や積雪 等の「物理的な障害の有無」に関する要因の值が 0.400 以上と高く重視されることがあげられる。 これは高齢期の特徴として先行研究でも明らかに されおり，それにより花園地区では「近隣ルー 卜」，奥沢地区では「国道ルート」の評価が高 い。花園地区では全てのルートが, 奥沢地区に比 べて比較的平坦であるが, 奥沢地区では「近隣 ルート」に急峻な坂や階段が多くみられ，国道

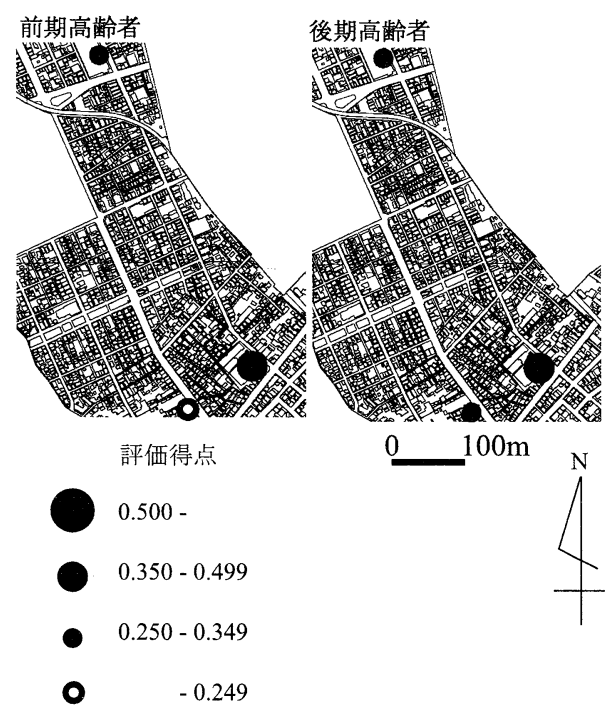

図12 商業施設の評価得点（花園地区）

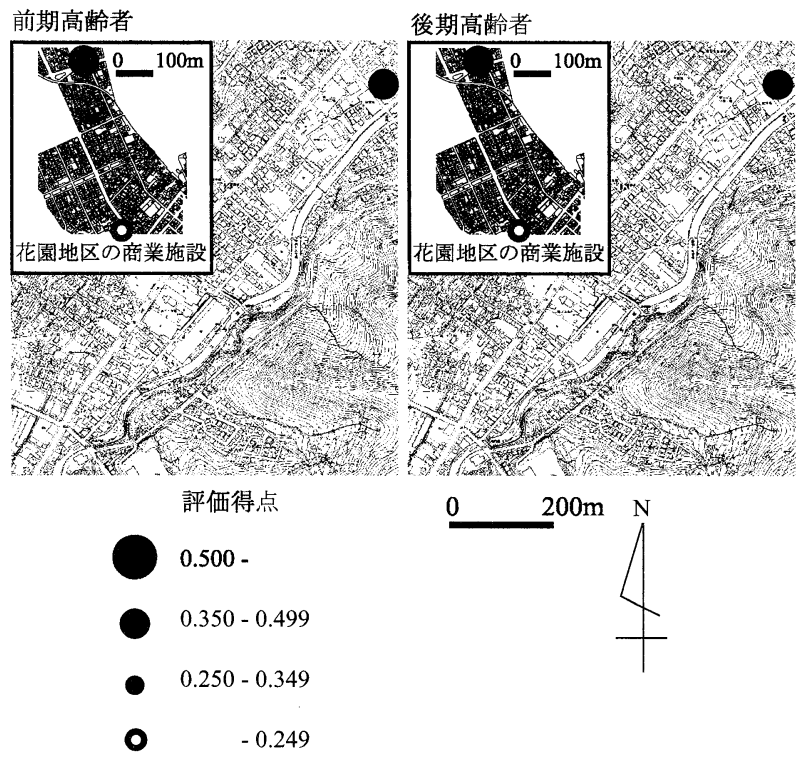

図13 商業施設の評価得点（奥沢地区） 
ルートや川沿いルートが比較的平坦である。その ようなことが，評価結果に反映されていると考え られる。まず，花園地区の評価得点をみると，3

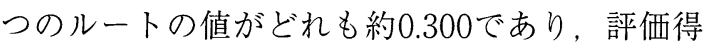
点に大きな差はみられず，全体として満足度の 高い生活環境が形成されていると考えられる（図 14）。前期高齢者と後期高齢者の違いによる評価 得点の差もほとんどみられない。また, 評価項目 の「交通量」や「雲囲気」は, ガードレールや街 灯が地区内の歩行路ではよく整備されているため に，3つのルートの評価得点の差が生じなかった ものと考えられる。次に奥沢地区では，上述した 「国道ルート」のみ評価得点が高く，特に前期高 齢者で顕著な結果がみられる（図15）。この結果 を評価項目から推測すると, 前期高齢者は, ルー トの「雲囲気」を比較的重視しており，ガード レール等で車道と歩行が分離され，街灯が整備さ れた「国道ルート」の環境が，高齢者に評価され ていると考えられる。図 5 , 図 6 の歩行パターン と関連させてみると，「国道ルート」は歩行頻度 の高いルートでもあり，日常生活での慣れや精通 度もそうした項目の評価が影響しているのではな いかと考えられる。逆に「川沿いルート」の評価 は, 比較的平坦な歩行路にも関わらず，他のルー トと比べて著しく低く，ガードレールや街灯の整 備の不備等の要因が反映された結果ではないかと 考えられる。

冬季の歩行路の解析結果から, 両地区共通の 特徵として，階段や積雪等の「物理的な障害」の 評価要因が夏季よりも高まり,さらに冬季では街 灯等の設置に関わる「ルートの雾囲気」も重視さ れる。特に両地区に扔いて後期高齢者で「ルート の雲囲気」の評価要因が重視され，それは冬季の 積雪と日照時間の短さなどが影響していると考え られる。まず，冬季の花園地区の解析結果をみる と, 前期高齢者では, 「近隣ルート」の評価得点 が高まり，一方で国道の評価得点が低くなる（図 16），己れは上述の日照時間が短くなり，日暮れ が早まることで, 歩行路への慣れや精通度といっ た高齢者の心理的・精神的な状況が解析結果に 反映され，「近隣ルート」の得点を高めたと考え られる。次に, 奥沢地区の解析結果をみると, 夏 季と同様に，前期高齢者も後期高齢者も「川沿い

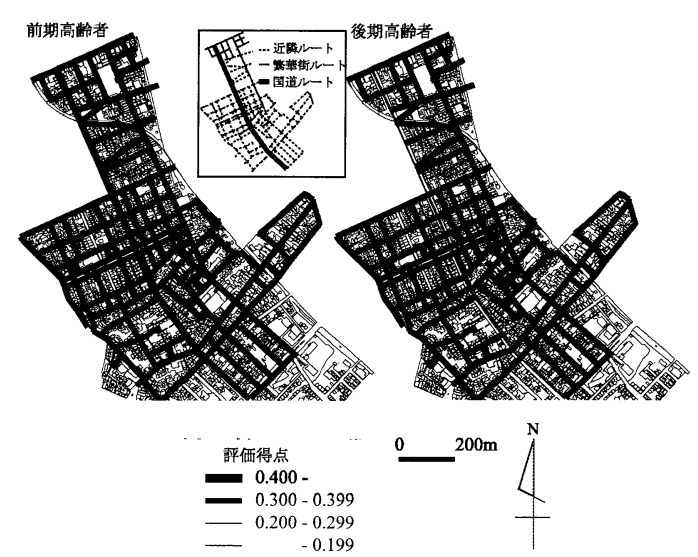

図14 歩行路の評価得点（花園地区）

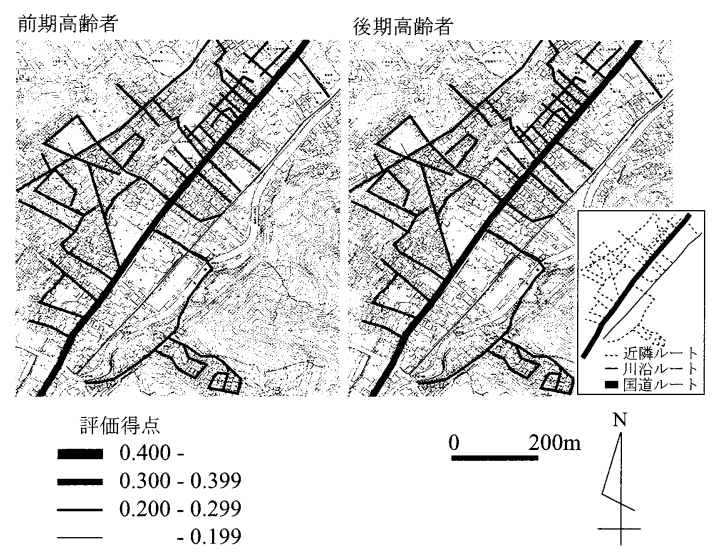

図15 歩行路の評価得点 (奥沢地区)

表 2 歩航路における評価ウエイトと評価得点 歩行路 (夏季)

\begin{tabular}{|c|c|c|c|c|}
\hline & \multicolumn{2}{|c|}{ 前期高齢者 } & \multicolumn{2}{|c|}{ 後期高齢者 } \\
\hline & 花園 & 奥沢 & 花園 & 奥沢 \\
\hline ルート外的要因 (交通量) & 0.299 & 0.234 & 0.224 & 0.242 \\
\hline ルート外的要因（雲囲気） & 0.204 & 0.328 & 0.321 & 0.306 \\
\hline 物理的な障害 & 0.497 & 0.438 & 0.455 & 0.452 \\
\hline 川沿いルート & & 0.153 & & 0.194 \\
\hline 国道ルート & 0.310 & 0.389 & 0.292 & 0.376 \\
\hline 近隣ルート & 0.390 & 0.242 & 0.362 & 0.220 \\
\hline 繁華街ルート & 0.300 & 0.216 & 0.346 & 0.210 \\
\hline \multicolumn{5}{|l|}{ 歩行路 (冬季) } \\
\hline & \multicolumn{2}{|c|}{ 前期高齢者 } & \multicolumn{2}{|c|}{ 後期高齢者 } \\
\hline & 花園 & 奥沢 & 花園 & 奥沢 \\
\hline ルート外的要因 (交通量) & 0.267 & 0.229 & 0.157 & 0.218 \\
\hline ルート外的要因（雲囲気） & 0.211 & 0.309 & 0.408 & 0.390 \\
\hline 物理的な障害 & 0.522 & 0.462 & 0.435 & 0.392 \\
\hline 川沿いルート & & 0.149 & & 0.163 \\
\hline 国道ルート & 0.245 & 0.390 & 0.337 & 0.390 \\
\hline 近隣ルート & 0.417 & 0.248 & 0.341 & 0.231 \\
\hline 繁華街ルート & 0.338 & 0.213 & 0.322 & 0.216 \\
\hline
\end{tabular}


ルート」と「国道ルート」の評価得点の間で大き な差がみられ（図17），「川沿いルート」の評価 得点は低く，一方で，「国道ルート」の得点は 高い ${ }^{16)}$ 。冬季で「国道ルート」の評価得点がよ り高まるのは，ガードレールや街灯の整備による ものと考えられる。奥沢地区では，冬季と夏季と いう季節の違いによる評価得点の差はあまりみら れず，前期高齢者と後期高齢者でも類似した評価 得点のパターンを示すことが明らかになる。その 点が3つのルートの評価得点に大差がない花園地 区との大きな違いである。さらに，それらの結果 を, 図 5 , 図 6 の歩行パターンと関連させて考察 すると,「川沿いルート」は通行量の多いルート に関わらず評価得点は低く，そのルートと並行す る「国道ルート」の通行量はほぼ同等であるが評 価得点は高い。上記の結果をまとめると，都心で

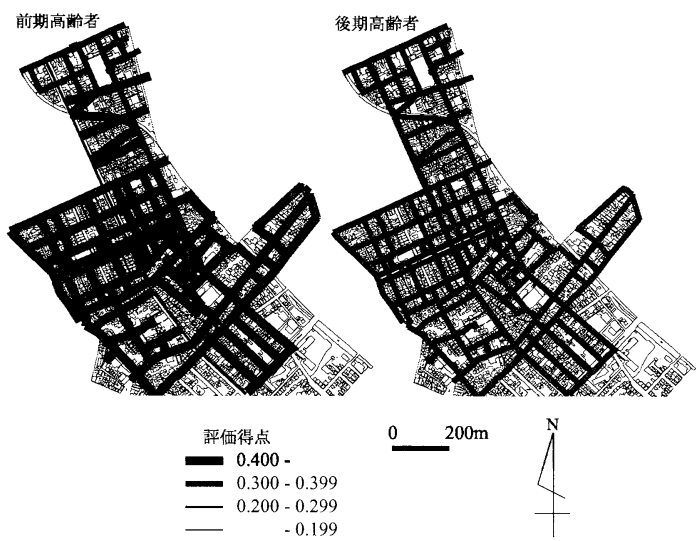

図16 冬季における歩行路の評価得点（花園地区）

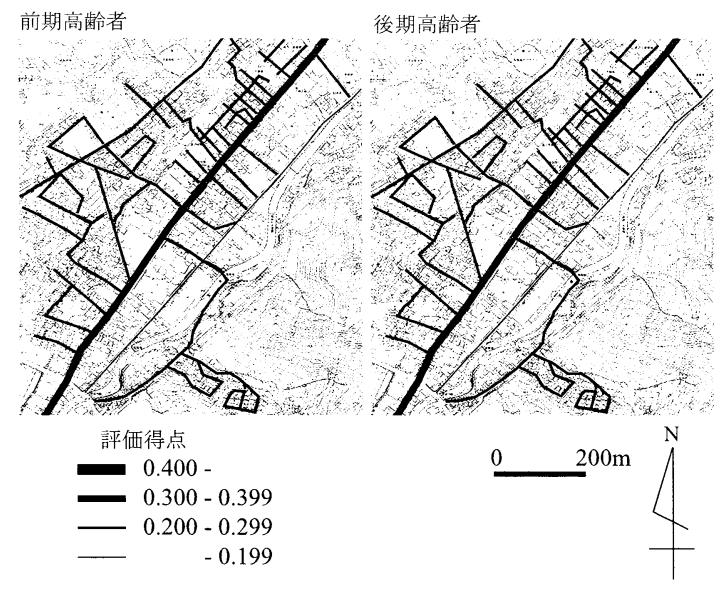

図17 冬季における歩行路の評価得点（奥沢地区）
は日常利用する道路の整備が進んでいるので，近 隣ルートに対する評価が高い。それに対して，郊 外では近接性を重視する住民が日常利用する歩行 路と, 街灯やガードレールの整備されている主要 道路が異なるために，上記のような通行量と評価 が対応しない状況が生じると考えられる。

\section{V.おわりに}

本研究では, 高齢者の歩行による生活環境下に おいて，どのような都市施設や歩行路を選択・利 用しているのかを把握し，それらの選択・利用し ている環境について，どのような評価をしている のかを明らかにし，積雪寒冷地域に打ける高齢者 の歩行による生活環境を解明した。その結果，以 下の点が明らかになった。

まず，小樽市において，高齢者特化指数が高い 地区は都心に多くみられる。そうした地域には, 平坦な土地が少なく，急峻な坂等の歩行による移 動が困難な地域である。

次に，都心の花園地区と，都市郊外の奥沢地区 で高齢者の歩行パターンを分析した結果，花園地 区では徒歩による都市施設の利用が多く，歩行路 も最短のルートを歩行する傾向がある。一方，奥 沢地区では，徒歩で利用できる都市施設が地区内 に少なく，バスと歩行を併用し，都市施設へ移動 することも多い。高齢者の外出頻度がどちらの地 域でも高いが，奥沢地区では特定の都市施設や歩 行路への依存が高く，1回あたりの歩行距離は， 奥沢地区が花園地区の約 2 倍の長さがあり，両地 区の比較から，歩行路の大きな差が解明された。

最後に，都市施設と歩行路に関する評価を AHPにより解析した結果，花園地区では，高齢 者の居住地近隣に複数の医療施設と商業施設が 存在し，それらを利用するために複数の歩行路を 利用する。医療施設では前期高齢者と後期高齢者 は同じ「施設の特性」という項目を重視しながら も，両属性の医療施設への思考特性の違いから， 前期高齢者は「総合病院」，後期高齢者は「個人 病院」の評価が高い。商業施設では，前期高齢者 と後期高齢者はそれぞれ違う項目を重視し，違う 都市施設を高く評価した。一方，奥沢地区では都 市施設に関して「利便性」の項目が重視され，医 療施設において, 「個人病院」と「総合病院」の 
評価得点の差が小さく，商業施設でも地区内に存 在する「生協」の評価得点が高い。そのように, 都心では, 都市施設の選択肢が多く, どの項目を 重視するかで，その項目に適した特性を持つ都市 施設を選択することが可能であるが，郊外では， 近接性の高さを重視するため, バスや歩行での交 通アクセスの良さが重要であり，生活環境下にお ける特定施設の認知や浸透の高さが, 評価得点の 高さに大きく影響し，それにより少数の都市施設 への依存度が高まる傾向があると考えられる。

夏季の歩行路に関して, 花園地区では 3 つの歩 行路に大きな得点差はみられず，それは良好な 道路整備が行われていることに起因しているもの と考えられる。一方, 奥沢地区では, 徒歩による 利用が多い「国道ルート」や「川沿いルート」の 間で大きな得点差がみられた。そして「国道ルー ト」の評価得点の高さも, 良好な道路整備が行わ れていることに起因しているものと考えられる。 冬季の歩行路に関しては,「物理的な障害」や, 「ルートの雲囲気」の項目が, 両地区において 重視される。これは冬季の積雪と日暮れの早さが 影響しているものと考えられる。歩行路の評価得 点をみると, 花園地区の前期高齢者は「近隣ルー ト」を高く評価しており, 一方, 奥沢地区では夏 季と同様に，「国道ルート」の評価が高く，「川 沿いルート」の評価が低い。上記の結果をまとめ ると, 都心では日常利用する道路の整備が進んで いるので，近隣ルートに対する評価が高い。それ に対し, 郊外は日常利用する歩行路と, 整備の進 んだ歩行路が一致しないために通行量と評価が対 応していない。

このようにAHPという手法により，高齢者の 生活環境下において, 使用する都市施設や歩行 路に打ける評価要因の解明と, 評価得点の解析か ら, 高齢者の物理的な運動能力や, 生活環境にお ける心理的な評価要因と歩行行動のギャップを解 明し, 空間的に視覚化することで, 地域環境の整 備の方向性等を考察できたことが本研究における 成果である。

本研究では, 冬季と夏季にそれほど明確に 高齢者の歩行に変化はみられず, 前期高齢者 と後期高齢者の加齢による行動特性の明確な違 いはあまりみることはできなかった。これは,
Corshall(1985)のいう「行動空間の縮小」は顕著 にはみられなかったことを意味し，加齢とは異な る他の要因が「行動空間の縮小」には関連してく る可能性がある。

なお, 本研究では比較的健康で, 歩行可能 な高齢者しか研究対象にできなかったが, 総 務庁編 (1998)によると約60\%の高齢者は, 日常 生活で何らかの障害を持っており, 外出行動 もそれらによって妨げられている。Gesler and Ricketts (1992)や杉浦（2005）は高齢者福祉サー ビス重要性を指摘しているが, 今後はそうした 歩行が困難な高齢者に着目し, 生活環境や地域社 会への認識や, ホームヘルパーやデイサービスと いった地域社会への参加を補助する要因の解析を 進め, 高齢者の生活環境におけるアメニティにつ いてより深く考察していくことも今後の課題であ る。

\section{謝辞}

本研究を作成するにあたり, 小樽市役所高齢福祉対策 課の品川宏平氏からは多くのご助言をいただきました。ま た, 塚田敏二氏，布沢正明氏をはじめとする小樽市老人会 の皆様には調查で多大なご協力をいただきました。また, 橋本雄一先生をはじめとする, 北海道大学大学院文学研究 科地域システム科学講座の諸先生方には終始ご指導を賜り ました。ここに記して厚く御礼申し上げます。

\section{注}

1) Warnes (1981)によると, 高齢者の地理学の分析 視角として1. 流動の人口統計学 (Demography of distribution)，2. 高齢者の移出入 (Migration of the elderly)， 3. 社会経済学々居住特性 (Socioeconomic and housing characteristics)，4.在宅サービス (Access to and delivery of Services), 5 .活動と 移動性のパターン(Activity patterns and mobility problems)が挙げられている。その後, Harper and Laws (1995) は近年における高齢者の地理学を展望 し, 老年学と地理学との関係性の薄さを懸念して, フェミニズムやポストモダニズムの観点から高齢者, 高齢化の解积を行った。

2) そうした研究からは勾配の急な坂, 長い階段, 幅員の 狭い箅所，さらには人込みや自動車交通量の多い道路 を避けるといった日常生活の徒歩における过回行動の 発生が指摘されている。なお, 高齢者の歩行能力は, 総務庁 (1998)によると, 日常生活で歩行を行っている 
高齢者 (60歳以上から85歳まで) は総数の $40 \%$ 以上, 15 分以上の比較的長い時間の歩行を行う数は総数の $30 \%$ 以上という調査結果があり, 新開ほか(1999)の研究で

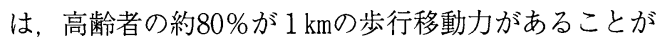
明らかになっている。欧州においても, Baltes et al. (1993)の調査により, ベルリン市において約40\%の 高齢者が歩行を伴う買い物行動を日常従事しているこ とが解明されている。

3 ）小樽市は, 明治期の港湾開発により, 産業が誘致さ れ，鉄道等の整備により，物資の集散地として商圏は 急速に拡大した。当時の市街地中心部は, 金融や経済 で北海道内最大の商業都市として繁栄していたが, そ の後, 内陸への開拓の進展, 道内他都市の成長や港湾 の整備などによって, 小樽市の商業都市としての相対 的地位は低下してきている。とりわけ戦後から現代に おいて，隣接する札幌市の都市機能の拡大等により小 樽市の経済的機能は衰退してきている(山内，2001)。 当市は現在 150,687 人 ( 2000 年国勢調査)の人口を有し ており, そのうち 65 歳以上の高齢者の人口は 35,253 人で, 総人口の $23.39 \%$ 䯩齢者であり，この比率は 年々高まりつつある。小樽市におけるDID地区は, 標 高の低い港湾付近から, 標高の高い地域へと形成され ている。これは港湾設備と利便性が高い地域で早くか ら会社や工場等の開発が行われ，それら施設で働く人 のための住宅整備が急峻な丘陵地で行われたためであ る。それら丘陵地で暮らす住民が近年は高齢化してき ており, 坂や階段が多い特質を持つ小樽市の生活環境 に適応するのが困難な状況にあると考えられる。

4）ゼンリンの住宅地図を用いて, 歩行路の記述を行っ た。

5 ）花園地区の後期高齢者の多くがそれらの施設へ安心と 信頼をよせている。

6 ）冬期間でも歩行ルートに大きな変化はないようであ る。これは花園地区にそれほど急勾配の土地が存在し ないことも一員ではないかと考えられる。

7 ) 当時, 小樽市では70歳以上の高齢者にバスが無料で利 用できる無料パスを配っていた。

8) AHP (Analytic Hierarchy Process)は, Saaty (1980) によって開発された。不確定な状況や多様な評価基準 における意思決定手法であり，いくつかの代替案の選 択や評価を行う際に主観的判断に基づいて問題解決し うる手法である(木下, 2000)。AHPでは問題の要素 を問題(最終目標), 評価基準, 代替案に分けて階層構 造としてとらえる。そして，問題に応じた評価基準の 重要度と, 評価基準からみた代替案の重要度を評価 し, 両者の重要度を勘案して最終的な代替案の評価を 行うものである。重要度の測定には, 評価基準あるい
は代替案の各要素を一対比較して重要度を主観的に評 価し, この一対比較行列から各要素間のウエイトを算 出する。一対比較の重要性を尺度として, 例えば次の ような值を用いる。

$1:$ 同じくらい重要

$3:$ やや重要

$5:$ かなり重要

7 : 非常に重要

$9:$ きわめて重要

ここで一対比較行列を $A$ とすると,

$A=\left[\begin{array}{cccc}w_{1} / w_{1} & w_{1} / w_{2} & \cdots & w_{1} / w_{n} \\ w_{2} / w_{1} & w_{2} / w_{2} & \cdots & w_{2} / w_{n} \\ \vdots & \vdots & & \vdots \\ w_{n} / w_{1} & w_{n} / w_{2} & \cdots & w_{n} / w_{n}\end{array}\right]$

であり，例えば,要素 1 と 2 を比較して，1の方が 2 よりも「かなり重要」であるならば, $w_{1} / w_{2}$ は $5 / 1$, すなわち 5 と評価される。逆に， $w_{2} / w_{1}$ は $1 / 5$ とな る。ここで，Aにウエイト・ベクトル $w=\left(w_{1}, w_{2} \cdots\right.$ $w_{n}$ ) をかけると,

$A w=\left[\begin{array}{cccc}w_{1} / w_{1} & w_{1} / w_{2} & \cdots & w_{1} / w_{n} \\ w_{2} / w_{1} & w_{2} / w_{2} & \cdots & w_{2} / w_{n} \\ \vdots & \vdots & & \vdots \\ w_{n} / w_{1} & w_{n} / w_{2} & \cdots & w_{n} / w_{n}\end{array}\right]\left[\begin{array}{c}w_{1} \\ w_{2} \\ \vdots \\ w_{n}\end{array}\right]=n\left[\begin{array}{c}w_{1} \\ w_{2} \\ \vdots \\ w_{n}\end{array}\right]$

を得る。ただし， $n$ は固有值である。このウエイト・ ベクトルが評価基準や代替案の各要素の重要度であ り，簡便な計算方法としては，一対比較ベクトルAの 行方向に幾何平均をとり, その幾何平均の総和でそれ ぞれの幾何平均を除して求めるとよい(木下，2000)。 また主観的判断に基づいて作成される一対比較行列 は，必ずしも首尾一貫性があるとは限らない。そこで 次式に示される首尾一貫性の尺度である整合度C.I.を 用いて判断する。

C.I. $=\frac{\lambda_{\max }-n}{n-1}$

ただし， $\lambda_{\text {max }}$ は一対比較行列の最大個有值， $n$ は要 素の数である。 $\lambda_{\text {max }}$ の簡便な算出方法は, 一対比較べ クトル Aの列方向に各要素のウエイトをかけ, 各要素 の行和に対して，それぞれの要素のウエイトで除す。 こうして得られた值の平均值が最大固有值である。 一般的に, 適合度は0.1未満であれば有効とみなされ る。なお, 本研究の解析における適合度はすべて 0.1 末満である。 
9 ）施設への魅力やコミュニティの多様性が高齢者の環 境評価に影響を及ぼすとという考察をしたBurby and Rohe(1990)の研究を参考にした。

10）この項目についても, Burby and Rohe(1990)を参考 にした。

11）自動車交通量のこと。狩野 (1993), 徳田・前川 (1999) が高齢期の歩行についてそうした要因を指摘してい る。

12）歩行路の䨌囲気(街灯の明るさ等の主観的な要因), 徳 田・前川 (1999)が高齢期の歩行についてそうした要因 を指摘している。

13）急峻な坂道や階段の有無, 三谷(1995)が歩行路につい てそうした要因を指摘している。

14）奥沢地区の各バス停から総合病院（小樽病院）付近の バス停は近く，本数も多く便利である。

15）夏季と冬季を想定して，聞き取り調査を行った。

16）調査結果から, 川沿いルートは街灯がなく，暗く，走 行する車が怖いと指摘する高齢者も多く存在する。

\section{参考文献}

石崎研二 (1998)：地理情報システムを用いた多摩ニュータ ウンの居住環境評価. 理論地理学ノート, 11, 31-52.

狩野 徹 (1993)：高齢者・障害者の道路交通計画. 秋山哲

男編：『高齢者の住まいと交通』日本評論社, 235-255.

木下栄蔵（1990）：階層分析法による道路の整備優先順位

の決定に関する研究. 交通工学, 25, No. 2，9-16.

木下栄蔵 (2000)：『入門AHP 決断と合意形成のテクニッ ク』日科技連.

榊原依子・萩原清子 (2004)：住環境整備と合意形成. 萩原

清子編：『環境の評価と意思決定』東京都立大学出版 会, 175-196.

新開省二 ·藤本弘一郎 - 渡部和子 · 近藤弘一 - 岡田克俊 $\cdot$

竇 貴旺 - 小西正光 · 小野ツルコ · 大西美智恵 · 田中昭 子・堀口 淳 (1999)：地域在宅老人の歩行移動力の現状 とその関連要因. 日本公衆衛生学会誌, 46, 35-46.

杉浦真一郎 (2005)：『地域と高齢者福祉 介護サービスの 需給空間』古今書院.

仙田裕子 (1993)：高龄者の生活空間一社会関係からの視点 一. 地理学評論, 66, 383-400.

相馬絵美・橋本雄一(2006)：空間デー夕におけるネット ワークボロノイ領域の分析方法. 北海道地理, 81 , 29-37.

総務庁編 (1998)：『高齢社会白書』総務庁.

中鉢奈津子 (1998)：京都市における高齢者の外出行動. 人 文地理, 50, 68-83.

徳田哲男 - 前川佳史 (1999)：題在宅高齢者の外出阻害要因 に関する研究．埼玉県立大学紀要，1，21-27.
刀根 薰 ·真鍋龍太郎編 (1990)：『AHP事例集』日科技 連.

星田侑久 (2006)：階層分析法の新しい適用方法：多数の観 点の定量化と評価得点の吟味に焦点をあてて. GIS-理 論と応用, 14, No. 2，135-144.

三谷 豪・杉浦芳夫 ·山根 拓(1995)：多摩ニュータウン 諏訪・永山地区における高齢者の分布とその住環境評価 に関する研究. 総合都市研究, 56, 5-35.

山内正明 (2001)：観光開発にかける商都の再生 小樽市. 平岡昭利編：『北海道地図で読む百年』古今書院, 21-26.

Baltes,P.B., Mayer,K.U., Helmchen,H. and SteinhagenThiessen,E.(1993) : The Berlin aging study: Over view and design. Aging and Society, 13,483-515.

Burby,J.R. and Rohe,M.W.(1990) : Providing for the housing needs of the elderly. Journal of American Planning Association, 56, 324-340.

Corshall,J.T.(1985) : Urban consumers cognitions of distance. Geografiska Annaler, 67B,107-119.

Gesler and Ricketts(1992) : Health in Rural North America The geography of health care Services and Delivery. Rutgers University Press.

Golant,S.M.(1972) : The residential location and Spatial behavior of the elderly. Department of geography research paper, 143, Univ. of Chicago.

Greenberg,L. (1982) : The implications of an aging population for land-use planning. Warnes,A.M. ed.: Geographical Perspectives on the Elderly. John Wiley \& sons, 401-425.

Hanson,P.(1977) : The activity patterns of elderly households. Geografiska Annaler, 59B,109-124.

Haper,S. and Laws,G.(1995) : Rethinking the geography of ageing. Progress in Human Geography, 19, 199-221.

Peace,S.M.(1982) : The activity patterns of elderly people in Swansea, South Wales, and South East England. Warnes,A.M. ed.: Geographical Perspectives on the Elderly. John Wiley \& sons, 281-302.

Saaty,T.L.(1980) : The Analytic Hierarchy Process. MacGraw-Hill.

Siddiqui,M.Z., Everett,J.W. and Vieux,B.E.(1996) : Landfill siting using Geographic Information Systems: a demonstration. Journal of Environmental Engineering, 122(6), 515-523.

Stutz,P.F.(1976) : Adjustment and mobility of elderly poor amid downtown renewal. The geographical review, 66, 391-400.

Warnes,A.M. (1981) : Towards a geographical 
contribution to gerontology. Progress in Human

Geography, 5, 317-341. 